Jahangirnagar University J. Biol. Sci. 6(1): 35-43, 2017 (June)

\title{
Management of brinjal shoot and fruit borer, Leucinodes orbonalis (Lepidoptera: crambidae) using some selected insecticides in field condition, Bangladesh
}

\author{
A. Awal ${ }^{1}$, M. M. Rahman, M. Z. Alam and M. M. H. Khan ${ }^{2 *}$ \\ Department of Entomology, Bangabandhu Sheikh Mujibur Rahman Agricultural \\ University, Gazipur-1706, Bangladesh
}

\begin{abstract}
Experiments were carried out in two consecutive cropping seasons to evaluate the effectiveness of seven insecticides against brinjal shoot and fruit borer (BSFB) in the experimental farm of the department of Entomology, BSMRAU, Bangladesh. Tracer-45 SC was found to be highly effective in reducing $88.22 \%$ and $84.41 \%$ shoot infestation over control during summer and winter, respectively followed by Proclaim-5 SG $(74.12 \%$ in summer and $64.36 \%$ in winter). The highest number of healthy fruits per plant $(22.38$ in summer and 35.69 in winter, respectively) and the highest yield of eggplant per hectare (19.94 $\mathrm{t} / \mathrm{ha}$ in summer and $24.79 \mathrm{t} / \mathrm{ha}$ in winter) were obtained from Tracer-45 SC treated plots. Therefore, it may be concluded that Tracer-45 SC (Spinosad) @ $0.4 \mathrm{ml} /$ liter could be the most effective insecticide in controlling brinjal shoot and fruit borer and also in getting highest yield of eggplant.
\end{abstract}

Key words: Eggplant, brinjal shoot and fruit borer, insecticide.

\section{INTRODUCTION}

Brinjal (Solanum melongena), also known as eggplant, belongs to the family Solanaceae. Its fruit commonly known as vegetable which is the most popular in Bangladesh. It is extensively grown both in summer and winter seasons and is available throughout the year. In Bangladesh, more than $70 \%$ of the total vegetables are produced in Rabi season and less than 30\% in the Kharif season (Hussain \& Awrangeb 1992). Nayar et al. (1995) reported 53 species of insect pests of brinjal among which brinjal shoot and fruit borer, Leucinodes orbonalis Guenee (Lepidoptera: Pyralidae), is the major and most destructive one in Bangladesh and throughout Asia. Larvae bore into shoots during the vegetative stage and later in flowers and fruits, rendering the latter unfit for human consumption. The yield loss caused by this pest is enormous and varies from $37 \%$ to $63 \%$ in different parts of India (Dhankar, 1988), up to 67\% every year in Bangladesh (Islam \& Karim, 1991). Latif, 2007 reported that Nimbicidene and Flubebdiamite were comparatively safe

\footnotetext{
${ }^{1}$ Upazilla Agriculture Officer, DAE, Arihazar, Narayanganj, Bangladesh

${ }^{2}$ Department of Entomology, Patuakhali Science and Technology University Dumki, Patuakhali, Bangladesh

*Corresponding author. E-mail: mohasin1965@pstu.ac.bd
} 
for natural enemies and insect pest management of brinjal on the other hand, Tohnishi et al. (2005) reported that flubendiamide was highly toxic to Lepidopteran insect pests but it was very safe for different natural enemies like ladybird beetles, spiders, parasitic wasp, lacewings, predatory bug and predatory mite.

In summer, temperature, relative humidity and rainfall remains high, while in winter conditions remain reverse. Depending on the weather condition, the prevalence of BSFB differs and it causes significant infestation in both the seasons. The effectiveness or performance of the insecticides are also greatly influenced by the temperature, relative humidity and rainfall under field conditions. The aim of this study was to investigate the comparative effectiveness of seven insecticides against BSFB in both the seasons and also to find out the most effective insecticide (s) for suppressing BSFB under field condition.

\section{MATERIALS AND METHODS}

Experiments were conducted in the experimental farm of the department of Entomology, Bangabandhu Sheikh Mujibur Rahman Agricultural University (BSMRAU), Gazipur, Bangladesh in two consecutive cropping seasons i.e. during summer (April to September 2009) and winter (November 2009 to May 2010). The experiments were laid out in a randomized complete block design (RCBD) with 3 replications. The whole field was divided into 3 blocks of equal size having space of 2 meters between blocks and 1.5 meters between plots. Each block was subdivided into 8 equal plots (Treatments) including one control plot. The unit plot size was $3 \mathrm{~m} \times 3 \mathrm{~m}$ accommodating 15 pits per plot. The distance between rows were $1 \mathrm{~m}$ and that of plants were $60 \mathrm{~cm}$. The application of manures and chemical fertilizers were done following by the method described by Rashid (1993). Seeds of brinjal variety BARI brinjal-8 were collected from the Horticultural Research Center (HRC) of Bangladesh Agricultural Research Institute (BARI), Joydebpur, Gazipur. A small seed bed measuring $5 \mathrm{~m} \times 1 \mathrm{~m}$ was prepared and seeds were sown in the nursery bed at Experimental field of the Department Entomology, BSMRAU, on 6 March 2009 for summer season and on 7 October 2009 for winter season. A total of 360 seedlings having 35 days old were planted in 24 plots @ 15 seedlings per plot with spacing of row to row $1.00 \mathrm{~m}$ and seedling to seedling $60 \mathrm{~cm}$. Weeding in the plots were done as and when necessary.

Treatments: Details of the application of in different plants (treatments) were as follows: $\mathrm{T}_{1}=$ Bactoil (Bacillus thuringiensis, Bt) @ $2 \mathrm{ml} /$ liter, $\mathrm{T}_{2}=$ Helicide (Heliothis Nuclear Polyhedrosis Virus, HNPV) @ $0.5 \mathrm{ml} /$ liter, $\mathrm{T}_{3}=$ Nimbicidene 0.03 EC (Azadirachtin) @ $4 \mathrm{ml} /$ liter, $\mathrm{T}_{4}=$ Tracer-45 SC (Spinosad) @ $0.4 \mathrm{ml} /$ liter, $\mathrm{T}_{5}=$ Proclaim5 SG (Emamectin benzoate) @ 1 gm/liter, $\mathrm{T}_{6}=$ Necstar-50 EC (Chlorpyriphos) @1 $\mathrm{ml} /$ liter, $\mathrm{T}_{7}=$ Boster-10 EC (Cypermethrin) @ $1 \mathrm{ml} /$ liter and $\mathrm{T}_{8}=$ Untreated control. The insecticides were applied with the help of Knapsac sprayer. The first application of insecticides were done after $4^{\text {th }}$ week of transplanting and subsequent applications were made at 7 days intervals. Precautions were taken to avoid drift to the adjacent plots. The effect of different treatments in controlling BSFB infestation was measured on the basis of infestation of shoots and fruits of eggplant and yield per hectare. 
Shoot infestation: The total numbers of shoots and the number of infested shoots were recorded from randomly selected 5 plants per plot at weekly intervals. Percent Shoot infestation was calculated using the following formula:

$\%$ Shoot infestation $=\frac{\text { Number of infested shoot }}{\text { Number of total shoot }} \times 100$

Fruit infestation and yield per hectare: After harvesting fruits at 7 days intervals, the healthy and infested fruits were sorted out. The weight of healthy and infested fruits of each plot for each treatment was noted separately. Fourteen harvests were made throughout the fruiting season and percent fruit infestation by number and weight was calculated using the following formulae:

$\%$ Fruit infestation (by number) $=\frac{\text { Number of infested fruits }}{\text { Number of total fruits }} \times 100$
$\%$ Fruit infestation (by weight) $=\frac{\text { Weight of infested fruits }}{\text { Weight of total fruits }} \times 100$

The cumulative plot yield of healthy, infested and total fruits of 12 harvests were transformed into healthy, infested and total yield per ha in tons.

Statistical analysis: Data were analyzed by using MSTAT-C software for analysis of variance. Analysis of variance was made by $\mathrm{F}$ variance test and mean separation was performed by Duncan's Multiple Range Test (DMRT) (Gomez \& Gomez, 1984).

\section{RESULTS AND DISCUSSION}

Effects on shoot infestation: The comparative effectiveness of insecticides on percent shoot infestation caused by BSFB in summer (April to September 2009) and winter (November 2009 to May 2010) are presented in Table 1. In summer, significantly lowest percent shoot infestation $(0.83 \%)$ was recorded in the plots treated with Tracer-45 SC followed by Proclaim-5 SG (1.82\%), Bactoil (2.76\%), Nimbicidene 0.03 EC (3.55\%) and Helicide $(4.28 \%)$. The highest percent $(7.02 \%)$ shoot infestation was observed in the untreated control plots followed by Necstar-50 EC (6.29\%) and Boster-10 EC (6.33\%) having no significant differences among them. In winter, the lowest percent $(0.78 \%)$ shoot infestation was also found in the plots treated with Tracer-45 SC (Spinosad) followed by Proclaim-5 SG (1.78\%). The highest percent shoot infestation $(5.00 \%)$ was in the untreated control plots followed by Boster-10 EC (4.24\%), Necstar-50 EC (3.66\%) and Helicide $(2.58 \%)$ having significant differences among them. The highest percent reduction $(88.22 \%)$ of shoot infestation over control was observed in Tracer-45 SC treated plots followed by Proclaim-5 SG (74.12\%), Bactoil (60.68\%), Nimbicidene 0.03 EC (49.39\%), Helicide (38.99\%), Necstar-50 EC (10.44\%) and Boster-10 EC (9.83\%) 
treated plots during summer season. In winter, similar trend also was recorded in the plots treated with Tracer-45 SC (84.41\%) followed by Proclaim-5 SG (64.36\%), Bactoil (59.36\%), Nimbicidene 0.03 EC (57.03\%), Helicide (48.37\%), Necstar-50 EC (26.78\%) and Boster-10 EC (15.19\%) treated plots (Table 1).

Table 1. Percentage brinjal shoot borer infestation and its management with selected insecticides in two cropping seasons of the year 2009-2010

\begin{tabular}{l|c|c|c|c}
\hline \multicolumn{1}{c|}{ Insecticides } & $\begin{array}{c}\text { \% shoot } \\
\text { infestation } \\
\text { in summer }\end{array}$ & $\begin{array}{c}\text { \% shoot } \\
\text { infestation } \\
\text { in winter }\end{array}$ & $\begin{array}{c}\text { \% shoot } \\
\text { infestation } \\
\text { reduction in } \\
\text { summer }\end{array}$ & $\begin{array}{c}\text { \% shoot } \\
\text { infestation } \\
\text { reduction in } \\
\text { winter }\end{array}$ \\
\hline Bactoil (Bt) & $2.76 \mathrm{e}$ & $2.03 \mathrm{e}$ & 60.68 & 59.36 \\
Helicide & $4.28 \mathrm{c}$ & $2.58 \mathrm{~d}$ & 38.99 & 48.37 \\
(HNPV) & $3.55 \mathrm{~d}$ & $2.15 \mathrm{e}$ & 49.39 & 57.03 \\
Nimbicidene 0.03 EC & $0.83 \mathrm{~g}$ & $0.78 \mathrm{~g}$ & 88.22 & 84.41 \\
Tracer-45 SC & $1.82 \mathrm{f}$ & $1.78 \mathrm{f}$ & 74.12 & 64.36 \\
(Spinosad) & & & & \\
Proclaim-5 SG (Emamectin & $6.29 \mathrm{~b}$ & $3.66 \mathrm{c}$ & 10.44 & 26.78 \\
benzoate) & $6.33 \mathrm{~b}$ & $4.24 \mathrm{~b}$ & 9.83 & 15.19 \\
Necstar-50 EC (Chloropyriphos) & $7.020 \mathrm{a}$ & $5.00 \mathrm{a}$ & - & - \\
Boster-10 EC (Cypermethrin) & $\mathbf{0 . 4 3}$ & $\mathbf{0 . 1 7}$ & - & - \\
Control & $\mathbf{6 . 0 0}$ & $\mathbf{3 . 5 0}$ & - & - \\
\hline LSD & & & \\
\% CV & &
\end{tabular}

Each data represents the average of 12 observations and that of 3 replications. Data in a column followed by the same letters are not significantly different $(\mathrm{P}<0.01$, Duncan Multiple Range Test $)$

Effectiveness on fruit infestation: The comparative effectiveness of insecticides on number of healthy, infested and total fruits per plant during summer (April to September 2009) and winter (November 2009 to May 2010) are presented in Table 2 and 3. In summer, the number of healthy fruits per plant was the highest (22.38) in Tracer-45 SC treated plots followed by Bactoil (17.98). The number of healthy fruits per plant was the lowest (8.58) in control which was statistically similar to Boster-10 EC (8.76) and Necstar-50 EC (8.93) followed by Helicide (13.07) and Proclaim-5 SG (16.78). The number of infested fruits per plant was the highest (8.38) in the untreated control plots followed by Helicide (5.27), Proclaim-5 SG (5.02) and Bactoil (4.69) (Table 2). The number of infested fruits per plant was the lowest (3.30) in the plots treated with Tracer45 SC followed by Necstar-50 EC (4.24), Boster-10 EC (4.18) and Nimbicidene 0.03 EC (4.10). In case of total fruits per plant, the number of fruits were the highest (25.55) in the plot treated with Tracer-45 SC, which was significantly higher than all other treatments including control followed by Bactoil (22.67), Proclaim-5 SG (21.80), Nimbicidene 0.03 EC (21.69) and Helicide (18.34). The number of total fruits per plant was the lowest in Necster-50 EC (13.18) and Bostar-10 EC (12.93) (Table 2).

The number of healthy fruits per plant was the lowest (15.54) in the plots treated with Boster-10 EC followed by Necstar-50 EC (19.69). 
Table 2. Average healthy, infested and total brinjal fruits produced in the experimental plots treated with some selected insecticides in two cropping seasons of the year 2009. 2010

\begin{tabular}{|c|c|c|c|}
\hline Insecticides & $\begin{array}{l}\text { Healthy fruits } \\
\text { per plant }\end{array}$ & $\begin{array}{l}\text { Infested fruits } \\
\text { per plant }\end{array}$ & $\begin{array}{l}\text { Total fruits per } \\
\text { plant }\end{array}$ \\
\hline \multicolumn{4}{|l|}{ Summer } \\
\hline Bactoil (Bt) & $17.98 \mathrm{~b}$ & $4.69 \mathrm{bc}$ & $22.67 \mathrm{~b}$ \\
\hline Helicide (HNPV) & $13.07 \mathrm{~d}$ & $5.27 \mathrm{~b}$ & $18.34 \mathrm{c}$ \\
\hline Nimbicidene 0.03 EC & $17.47 \mathrm{bc}$ & $4.10 \mathrm{c}$ & $21.69 \mathrm{~b}$ \\
\hline Tracer-45 SC (Spinosad) & $22.38 \mathrm{a}$ & $3.30 \mathrm{~d}$ & $25.55 \mathrm{a}$ \\
\hline Proclaim-5 SG & $16.78 \mathrm{c}$ & $5.02 \mathrm{~b}$ & $21.80 \mathrm{~b}$ \\
\hline \multicolumn{4}{|l|}{ (Emamectin benzoate) } \\
\hline Necstar-50 EC (Chloropyriphos) & $8.93 \mathrm{e}$ & $4.24 \mathrm{c}$ & $13.18 \mathrm{e}$ \\
\hline Boster-10 EC (Cypermethrin) & $8.76 \mathrm{e}$ & $4.18 \mathrm{c}$ & $12.93 \mathrm{e}$ \\
\hline Control & $8.58 \mathrm{e}$ & $8.38 \mathrm{a}$ & $16.95 \mathrm{~d}$ \\
\hline LSD & 1.14 & 0.69 & 1.13 \\
\hline$\% \mathrm{CV}$ & 4.59 & 7.98 & 3.38 \\
\hline \multicolumn{4}{|l|}{ Winter } \\
\hline Bactoil (Bt) & $24.27 \mathrm{~b}$ & $4.60 \mathrm{f}$ & $28.87 \mathrm{c}$ \\
\hline Helicide (HNPV) & $18.89 \mathrm{~d}$ & $6.27 \mathrm{c}$ & $25.16 \mathrm{e}$ \\
\hline Nimbicidene 0.03 EC & $22.42 \mathrm{c}$ & $5.64 \mathrm{~d}$ & $28.02 \mathrm{~cd}$ \\
\hline Tracer-45 SC (Spionsad) & $35.69 \mathrm{a}$ & $4.07 \mathrm{~g}$ & $39.76 \mathrm{a}$ \\
\hline Proclaim-5 SG (Emamectin benzoate) & $24.09 \mathrm{~b}$ & $5.16 \mathrm{e}$ & $29.24 \mathrm{c}$ \\
\hline Necstar-50 EC (Chlorpyriphos) & $19.69 \mathrm{~d}$ & $7.78 \mathrm{~b}$ & $27.47 \mathrm{~d}$ \\
\hline Boster-10 EC (Cypermethrin) & $15.54 \mathrm{e}$ & $5.38 \mathrm{de}$ & $20.91 \mathrm{f}$ \\
\hline Control & $22.35 \mathrm{c}$ & $9.92 \mathrm{a}$ & $32.24 \mathrm{~b}$ \\
\hline LSD & 1.33 & 0.46 & 1.29 \\
\hline$\% \mathrm{CV}$ & 3.33 & 4.28 & 2.53 \\
\hline
\end{tabular}

Each data represents the average of 12 observations and that of 3 replications. Data in a column followed by the same letters are not significantly different $(\mathrm{P}<0.01$, Duncan Multiple Range Test)

However, the highest percent fruit damage (49.07) was observed in the control plots, which was significantly higher than all the insecticide-treated plots (Table 3).

In summer, the reduction of fruit damage was the highest (74.65\%) in Tracer-45 SC treated plots followed by Bactoil (59.69\%), Proclaim-5 SG (57.92\%), Nimbicidene 0.03 EC (53.07\%), Helicide (41.47\%), Necstar-50 EC (34.36\%) and Boster-10 EC (34.05\%). In winter the reduction of fruit damage over control was the highest $(66.86 \%)$ in the plots treated with Tracer-45 SC followed by Bactoil (48.13\%), Proclaim-5 SG (42.26\%), Nimbicidene 0.03 EC (34.37\%), Helicide (18.16\%), Necstar-50 EC (16.11\%) and Boster$10 \mathrm{EC}(7.63 \%)$.

Effectiveness on yield (t/ha) of brinjal: The reduction of shoot and fruit infestation due to insecticide application ultimately improved the yield of brinjal Table 3 . The results revealed that during summer the healthy fruit yield was the highest (19.94 t/ha) in Tracer$45 \mathrm{SC}$ treated plots which differed significantly than all other treatments. The healthy 
fruit yield was the lowest in the plots treated with Boster-10 EC (7.04 t/ha) which was statistically similar to untreated control $(7.27 \mathrm{t} / \mathrm{ha})$ and Necstar-50 EC (7.58 t/ha) treated plots (Table 3).

The total fruit yield was the highest (22.82 $\mathrm{t} / \mathrm{ha}$ ) in Tracer-45 SC treated plots followed by Proclaim-5 SG (17.50 t/ha) and Nimbicidene 0.03 EC (16.96 t/ha), both being staistically identical. The lowest total fruit yield was recorded in plots treated with Boster-10 EC (10.30 t/ha) and Necstar-50 EC (10.85 t/ha), both being statistically similar followed by control plots (14.00 t/ha) and Helicide (13.45 t/ha), (Table 3).

Table 3. Yield of brinjal fruits (healthy, infested and total) from the experimental plots treated with some selected insecticides during summer and winter, 2009-2010

\begin{tabular}{|c|c|c|c|c|c|c|}
\hline \multirow{3}{*}{ Insecticides } & \multicolumn{6}{|c|}{ Yield of brinjal fruit (t/ha) } \\
\hline & \multicolumn{3}{|c|}{$\begin{array}{c}\text { Summer } \\
\text { (April to September, 2009) }\end{array}$} & \multicolumn{3}{|c|}{$\begin{array}{c}\text { Winter } \\
\text { (November } 2009 \text { to May 2010) }\end{array}$} \\
\hline & $\begin{array}{l}\text { Healthy } \\
\text { fruits }\end{array}$ & $\begin{array}{l}\text { Infested } \\
\text { fruits }\end{array}$ & Total & $\begin{array}{l}\text { Healthy } \\
\text { fruits }\end{array}$ & $\begin{array}{l}\text { Infested } \\
\text { fruits }\end{array}$ & Total \\
\hline Bactoil (Bt) & $12.96 \mathrm{~b}$ & $3.16 \mathrm{c}$ & $16.12 \mathrm{c}$ & $17.11 \mathrm{bc}$ & $2.83 \mathrm{ef}$ & $19.94 \mathrm{c}$ \\
\hline Helicide (HNPV) & $9.65 \mathrm{c}$ & $3.80 \mathrm{~b}$ & $13.45 \mathrm{~d}$ & $14.46 \mathrm{~d}$ & $5.33 \mathrm{~b}$ & $19.80 \mathrm{c}$ \\
\hline $\begin{array}{l}\text { Nimbicidene } 0.03 \\
\text { EC }\end{array}$ & $13.76 \mathrm{~b}$ & $3.20 \mathrm{c}$ & $16.96 \mathrm{bc}$ & $16.37 \mathrm{c}$ & $3.70 \mathrm{~cd}$ & $20.07 \mathrm{c}$ \\
\hline $\begin{array}{l}\text { Tracer-45 SC } \\
\text { (Spinosad) }\end{array}$ & $19.94 \mathrm{a}$ & $2.87 \mathrm{c}$ & $22.82 \mathrm{a}$ & $24.79 \mathrm{a}$ & $2.48 \mathrm{f}$ & $27.27 \mathrm{a}$ \\
\hline $\begin{array}{l}\text { Proclaim-5 SG } \\
\text { (Emamectin } \\
\text { benzoate) }\end{array}$ & $13.56 \mathrm{~b}$ & $3.95 \mathrm{~b}$ & $17.50 \mathrm{~b}$ & $17.70 \mathrm{~b}$ & $3.15 \mathrm{e}$ & $20.83 \mathrm{c}$ \\
\hline $\begin{array}{l}\text { Necstar-50 EC } \\
\text { (Chlorpyriphos) }\end{array}$ & $7.58 \mathrm{~d}$ & $3.27 \mathrm{c}$ & $10.85 \mathrm{e}$ & $14.11 \mathrm{~d}$ & $3.96 \mathrm{c}$ & $18.07 \mathrm{~d}$ \\
\hline $\begin{array}{l}\text { Boster-10 EC } \\
\text { (Cypermethrin) }\end{array}$ & $7.04 \mathrm{~d}$ & $3.27 \mathrm{c}$ & $10.30 \mathrm{e}$ & $10.91 \mathrm{e}$ & $3.31 \mathrm{de}$ & $14.22 \mathrm{e}$ \\
\hline Control & $7.27 \mathrm{~d}$ & $6.74 \mathrm{a}$ & $14.00 \mathrm{~d}$ & $10.37 \mathrm{e}$ & $7.17 \mathrm{a}$ & $17.54 \mathrm{~d}$ \\
\hline LSD & 1.18 & 0.36 & 1.28 & 1.17 & 0.48 & 1.63 \\
\hline$\% \mathrm{CV}$ & 5.85 & 5.46 & 4.80 & 4.01 & 6.80 & 4.50 \\
\hline
\end{tabular}

Each data represents the average of 14 observations and that of 3 replications. Data in a column figures followed by the same letter are not significantly different $(\mathrm{P}<0.01$, Duncan Multiple Range Test)

Accordingly total fruit yield was the highest (27.27 t/ha) in Tracer-45 SC treated plots followed by Proclaim-5 SG (20.83 t/ha), Nimbicidene 0.03 EC (20.07 t/ha), Bactoil (19.94 t/ha) and Helicide (19.80 t/ha), the last four being statistically similar. The lowest total fruit yield (14.22 $\mathrm{t} / \mathrm{ha}$ ), was recorded in the plots treated with Boster-10 EC followed by Necstar-50 EC (18.07 t/ha) and contorl (17.54 t/ha), the last two also being statistically similar (Table 3).

Thus, based on the findings of Table 1, Tracer-45 SC could be considered as the most effective insecticide against BSFB in reducing shoot infestation in winter, while 
Proclaim-5 SG, Bactoil and Nimbicidene 0.03 EC could be moderately effective in both seasons. Helicide showed moderate effectiveness in winter season and less effectiveness in summer season while Necstar $50 \mathrm{EC}$ and Boster $10 \mathrm{EC}$ both showed less effectiveness in both seasons. Adiroubane \& Raghuraman (2006) reported that the percent reduction of shoot damage ranged between 84.36 to 93.82 in case of Spinosad and 75.41 to 85.38 in Carbaryl + Wettable sulphur. Patra et al. (2009) found the the lowest mean shoot as well as fruit infestation (7.47 and 9.88 \%) in the plots treated with Spinosad 2.5 SC (50 g ai ha ${ }^{1}$ ) followed by Indoxacarb 14.5 SC $50 \mathrm{~g}$ ai ha ${ }^{-1}$ (8.89 and 13.13\%) and Emamectin benzoate 5 SG $15 \mathrm{~g}_{\text {ai }} \mathrm{ha}^{-1}(10.95$ and $16.66 \%)$, respectively in a field experiment. The mean percent fruit infestation was the lowest $(9.88 \%)$ in the plots treated with Spinosad 2.5 SC followed by Indoxacarb 14.5 SC (13.13\%), Emamectin benzoate 5 SG (16.66\%) under field condition was reported by Patra et al., 2009. Kabir et al. (1996) evaluated several insecticides (Ralothrin 10 EC, Sunfuran 36 EC, Fenom 10 EC, Selecron 50 EC, Fastac 2 EC, Decis 2.5 EC, Arrivo 10 EC, Shobicron 4.25 EC, Cymbush 10 EC, Ripcord 10 EC, Nogos 10 EC) against BSFB over three consecutive seasons at Gazipur and Jessore district of Bangladesh and reported that none of the tested insecticides had significant effect in reducing the pest population. The less effectiveness of Nimbicidene 0.03 EC was reported by Latif (2007), which was similar to the present study. He recorded $4.31 \%$ shoot infestation in the plots treated with Nimbicidene 0.03 EC while it was $7.01 \%$ in untreated control plots. Puranik et al. (2002) reported minimum shoot $(1.56 \%)$ as well as fruit $(11.78 \%)$ infestation and maximum yield of marketable fruits (196.96 q/ha) when five sprays of Dipel 8L(Bt) @ 0.2 percent at 10 days interval were applied and proved to be the most effective treatment. The lower effectiveness of Helicide was in accordance with the finding of the study of Ghimire et al. (2007). He recorded, higher fruit infestation both in terms of number and weight with $\mathrm{NPV}+$ Margosom $(34.51 \pm 1.76$ and $31.62 \pm 2.64 \%)$ which was $(42.30 \pm 4.56$ and $43.57 \pm$ $8.9 \%$ ) with untreated control, respectively.

The results obtained in the present study suggest that the application of Tracer-45 SC performed the best in ensuring higher healthy fruit yield as well as total fruit yield of brinjal in both winter and summer seasons. Awal et al. (2014) found that Tracer-45 SC, Bactoil, Proclaim-5 SG demonstrated significantly higher mortality against $4^{\text {th }}$ instar larvae of BSFB. Jat \& Preek (2001) and Misra (1993) reported that Nimbicidene was the least effective insecticide in controlling the BSFB and resulted in the lowest yield but Srinibvasan et al. (1998) reported that Nimbicidene provided higher yield (13.02 t/ha) than Endosulfan. Bactoil and Tracer-45 SC were relatively safe for natural enemies and therefore would be fit well into integrated pest management (IPM) against BSFB of brinjal crop (Awal, et al., 2015).

Therefore, it may be concluded here that the Tracer-45 SC (Spinosad) could be used in protecting the brinjal crop against BSFB and thus may ensure the highest yield per plants in both the summer and winter seasons in Bangladesh. 


\section{REFERENCES}

Adiroubane, D. and Raghuraman, K. 2006. IPM in brinjal shoot and fruit borer management $J$. Biopest. 1(2): 124 - 129 .

Awal, A., Rahman, M. M., Alam, M. Z., Khan, M. M. H., Kabir, A. K. M. R. and Uddin, M. S. 2014. Efficacy of seven insecticides on the larvae of brinjal shoot and fruit borer, Leucinodes orbonalis Guenee under laboratory condition. J. Patuakhali Sci. and Tech. Univ. 5(1): 37-43.

Awal, A., Rahman, M. M., Alam, M. Z. and Khan, M. M. H. 2015. Diversity and equitability of insect pests and natural enemies in brinjal field treated with insecticides. Jahangirnagar University J. Biol. Sci. 4(1):71-80.

Dhankar, D. S. 1988. Progress in résistance studies in eggplant (Solanum melongena L.) against shoot and fruit borer of brinjal (Leucinodes orbonalis Guenee) infestation. Trop. pest manage. 34: 343-345

Ghimire, S. N., Upreti, G., Thapa, R. B. and Manandhar, D. N. 2007. Eco-friendly management of brinjal fruit and shoot borer, Leucinodes orbonalis Guenee (Lepidoptera: Pyrallidae). IAAS Research Advances Vol. 2. Institute of Agriculture and Animal Sciences, Rampur, Chitwan, Nepal, 127-131

Gomez, K. A. and Gomez, A. A. 1984. Statistical procedures of agricultural research. $2^{\text {nd }}$ Edn. International Rice Research Institute, John Willey and Sons, Inc. Singapure, 139-240

Hossain, A. and Awrangzeb, S. N. H. 1992. Vegetable production policies, present and future directions, pp. 21-30, In: Proceeding on vegetable production and marketing. AVRDC, BARI, BARC and USAID

Islam, M. N. and Karim, M. A. 1991. Management of the brinjal shoot and fruit borer, Leucinodes orbonalis Guenee (Lepidoptera: Pyralidae) in field. Annual Ressearch Report, 1990-1991. Ent. Div. Bangladesh Agricultural Research Institute, Joydebpur, Gazipur, Bangladesh, 44-46

Islam, M. N. and Karim, M. A. 1993. Screening insecticides for the brinjal shoot and fruit borer. Annual Report. 1992-93. BARI, Gazipur, Bangladesh.

Jat, K. L. and Preek, B. L. 2001. Field evaluation of ecofriendly insecticides against brinjal shoot and fruit borer (Leucinodes orbonalis Guenee), Indian J. Plant Protection. 29(1-2): 7585 .

Kabir, K. H., Baksh, M. E., Rouf, F. M. A., Karim, M. A. and Ahmed, A. 1996. Insecticide usage pattern on vegetables at farmers' level of Jessore region in Bangladesh: A survey finding. Bangladesh J. Agril. Res. 21: 241-254.

Latif, M. A. 2007. Ph. D. Dissertation on, "Effectiveness of some insecticides in managing brinjal shoot and fruit borer, Leucinodes orbonalis Guenee and their impact on arthropod biodiversity and soil microbial respiration", Bangabandhu Sheikh Mujibur Rahman Agricultural University (BSMRAU), Salna, Gazipur, Bangladesh.

Misra, H. P. 1993. Chemical control of brinjal shoot and fruit borer Leucinodes orbonalis Guen. Indian J. Entomol. 55(1): 89-91.

Nayar, K. K., Ananthakrishnan, T. N. and David, B. V. 1995. General and Applied Enotmology. $11^{\text {th }}$ edn. Tata MeGraw-Hill Publ. Co. Ltd. 4/12, Asaf Ali Road, New Delhi-110002. pp. 557.

Patra, S., Chatterjee, M. L., Shanowly, M. and Samanta, A. 2009. Field evaluation of some new insecticides against brinjal shoot and fruit borer, Leucinodes orbonalis (Guen.). Pesticide Res. J. 21(1): 58-60.

Puranik, T. R., Hadapad, A. R., Salunke, G. N. and Pokharkar, D. S. 2002. Management of shoot and fruit borer Leucinodes orbonalis through Bacillus thuiringiensis formulations on brinjal. J. Entomol. Res. 16 : 229-232. 
Rashid, M. M. 1993. Begum Paribarer Shabji. In: Shabji Biggan (in Bangla). First Edn. Bangla Academy, Dhaka, Bangladesh.

Srinivasan, G., Babu, P. C. S., Reddy, P. P., Kumar, N. K. K. and Verghese, A. 1998. Advances in IPM for Horticultural crops. Proceedings of the First National Symposium on Pest Management in Horticultural Crops: Environmental implications and thrust, Bangalore, India, 15-17 October, 1997. pp. 87-93.

Tohnishi, M., Nakao, H., Furuya, T., Seo, A., Kodama, H., Tsubata, K., Fujioka, S., Hirooka, S. and Nishimatsu, T. 2005. Flubendiamide, a novel insecticide highly active against Lepdopterous insect pests. J. Pestic. Sci. 30(4): 354-360. 